\title{
Pre-Messinian ecological diversity of Mediterranean sharks revealed by the study of their dermal denticles
}

\author{
Humberto G. FERRÓN ${ }^{I^{*}}$, José Luis HERRÁIZ ${ }^{*}$, Héctor BOTELLAI \& Carlos MARTÍNEZ- \\ PÉREZ ${ }^{1,2}$
}

${ }^{1}$ Cavanilles Institut of Biodiveristy and Evolutionary Biology, C/Catedrático José Beltrán Martínez n 2, 46980 Paterna, Valencia, Spain; Humberto.Ferron@uv.es; joheca@alumni.uv.es; Hector.Botella@uv.es; Carlos.Martinez-Perez@uv.es.

${ }^{2}$ School of Earth Sciences, University of Bristol, Life Sciences Building, 24 Tyndall Avenue, BS8 1TQ, Bristol, UK

*Corresponding author

Ferrón, H.G., Herráiz, J.L., Botella, H. \& Martínez-Pérez, C. 2019. Pre-Messinian ecological diversity of Mediterranean sharks revealed by the study of their dermal denticles. [Diversidad ecológica pre-Messiniense en tiburones del Mediterráneo según un estudio de sus dentículos dérmicos]. Spanish Journal of Palaeontology, 34 (2), 289-298.

Manuscript received 12 December 2018

Manuscript accepted 28 May 2019 https://doi 10.7203/sjp.34.2.16118

(C) Sociedad Española de Paleontología ISSN 2255-0550

\begin{abstract}
The Messinian salinity crisis $(\sim 5.59 \mathrm{Ma})$ is regarded as one of the most determining events for the recent evolutionary and palaeobiogeographic history of the Mediterranean biota. The impact of such episode has usually been assessed by evaluating the associated taxonomic turnover, however its consequences have rarely been interpreted from an ecological perspective. Here we assess the functional diversity of shark dermal denticles in a Serravallian locality from southeast Spain, providing a primary view into the preMessinian ecological diversity of shark communities from the Western Mediterranean. Our results reveal a high diversity of functional types of dermal denticles including dermal denticles that prevent the settlement of ectoparasites and epibionts, abrasion resistant dermal denticles, drag reduction dermal denticles and dermal denticles with less specific, or more generalized, functions. This variety of dermal denticles supports the presence of several ecological groups of sharks such as schooling and strong swimming species and, possibly, demersal species, slow sharks of the open water and, possibly, bioluminescent taxa. Therefore, the application of this methodology to Pliocene and Pleistocene fossiliferous sites
\end{abstract}

\section{RESUMEN}

La crisis de salinidad del Mesiniense $(\sim 5,59 \mathrm{Ma})$ es considerada como uno de los eventos más determinantes de la historia evolutiva y paleobiogeográfica reciente de la biota del Mediterráneo. Generalmente, el impacto de esta crisis se ha evaluado mediante el estudio de cambios de diversidad o reemplazamientos taxonómicos, sin embargo, sus consecuencias rara vez se han interpretado desde una perspectiva ecológica. En el presente trabajo estudiamos la diversidad funcional de escamas de tiburón encontradas en una localidad de edad Serravalliense del sureste de España, proporcionando una primera visión de la diversidad ecológica pre-Mesiniense de las comunidades de tiburones del Mediterráneo occidental. Nuestros resultados revelan una diversidad relativamente alta de tipos funcionales de dentículos dérmicos que incluyen escamas que previenen el asentamiento de ectoparásitos y epibiontes, escamas resistentes a la abrasión, escamas de reducción de la resistencia al avance y escamas con funciones generalizadas. Esta diversidad de dentículos dérmicos apoya la presencia de varios grupos ecológicos de tiburones, como formadores de cardúmenes, nadadores activos, especies demersales, 
will be crucial for unravelling the impact of Messinian salinity crisis and other recent geological events from an ecological perspective, allowing us to understand the shark community composition and diversity of the current Mediterranean Sea.

Keywords: Dermal denticles, functional ecology, morphometrics, Serravallian, Western Mediterranean.

\section{INTRODUCTION}

The Messinian salinity crisis ( $\sim 5.59 \mathrm{Ma})$ constitutes one of the most important episodes of the recent geological history of the Mediterranean region (Krijgsman et al., 1999; Gibert et al., 2013). This event involved the almost complete desiccation of the Mediterranean Sea, drastically reducing available ecosystems and driving most species to extinction (Coll et al., 2010). Among the affected taxa, chondrichthyans were especially vulnerable to this episode, particularly if we consider its impact on deep-sea communities (Martínez-Pérez et al., 2018 and references therein). The consequences of the Messinian salinity crisis in this group have usually been assessed through the evaluation of the nature and magnitude of taxonomic turnover by comparing pre- and post-Messinian faunal listings derived from purely systematic works (e.g., Marsili, 2008; Martínez-Pérez et al., 2018). However, the impact of such event on the ecological diversity of Mediterranean sharks and rays remains poorly explored so far.

Interestingly, the squamation of sharks has been revealed as an important source of ecological information (Reif, 1978, 1982, 1985a; Reif \& Dinkelacker, 1982; Fulgosi \& Gandolfi, 1983; Bechert et al., 1985; Muñoz-Chápuli, 1985; Raschi \& Musick, 1986; Raschi \& Tabit, 1992; Ball, 1999). Their dermal denticles show an important morphological variation between different species, sexes and within the same specimen through the ontogeny and between different regions of the body (see Ferrón \& Botella, 2017 and references therein). The different dermal denticle morphologies have been related with at least four different functions, including protection against abrasion with the substrate and prey, defence against the settlement of ectoparasites and epibionts, reduction of the skin friction drag and enabling the accommodation of photophores in bioluminescent species (Reif, 1982, 1985a). The recent publication of some works aiming to define such specific functional types through morphometric and multivariate procedures has established the basis for making functional and ecological inferences in extinct groups with similar squamations supported on quantitative and statistically tiburones de nado lento de aguas abiertas y, posiblemente, especies bioluminiscentes. La aplicación de esta metodología a yacimientos con fósiles de tiburones del Plioceno y Pleistoceno será crucial para desvelar el impacto de la crisis de salinidad del Mesiniense desde una perspectiva ecológica sobre las comunidades de tiburones del Mediterráneo, que nos permita comprender su historia evolutiva más reciente.

Palabras clave: Dentículos dérmicos, ecología funcional, morfometría, Serravaliense, Mediterráneo occidental.

\section{MATERIALS, METHODS, AND GEOGRAPHIC CONTEXT}

All the studied material comes from the "El Chorrillo" outcrop which belongs to the External Domains of the Betic Ranges, being located in the centre of the Alicante Province (southeast Spain), $3 \mathrm{~km}$ South from the Sax village at the left bank of the Vinalopó River (Fig. 1). "El Chorrillo" outcrop is constituted by massive sandstones and calcarenites comprising an abundant invertebrate fauna, dated as Serravallian (13.5-11.5 Ma) according to the foraminiferal association (Martínez del Olmo et al., 1978). The study area was part of the so-called North Betic Strait constituting the connection of the Atlantic Ocean with the Mediterranean during the Serravallian (Geel et al., 1992), previous to the closure and the partial desiccation of the later in Messinian time (Gibert et al., 2013) (see Martínez-Pérez et al., 2018 and references therein for more detailed information on the geological context).

The fossil specimens were recuperated after dissolving (c.a. $5-7 \%$ ) $50 \mathrm{~kg}$ of an isolated sample taken from a calcarenitic-microconglomerate level at the base of the "El Chorrillo" outcrop (see Martínez-Pérez et al., 2018). The residues were washed and screened in sieves with decreasing mesh sizes (i.e., 2, 0.4, 0.125, and $0.063 \mathrm{~mm}$, respectively). Subsequently, the microremains were picked up under a binocular microscope and photographed using the electron microscope Hitachi S4800 of the Central Service for Experimental Research of the University of Valencia, Spain. All specimens are housed at the Museu 


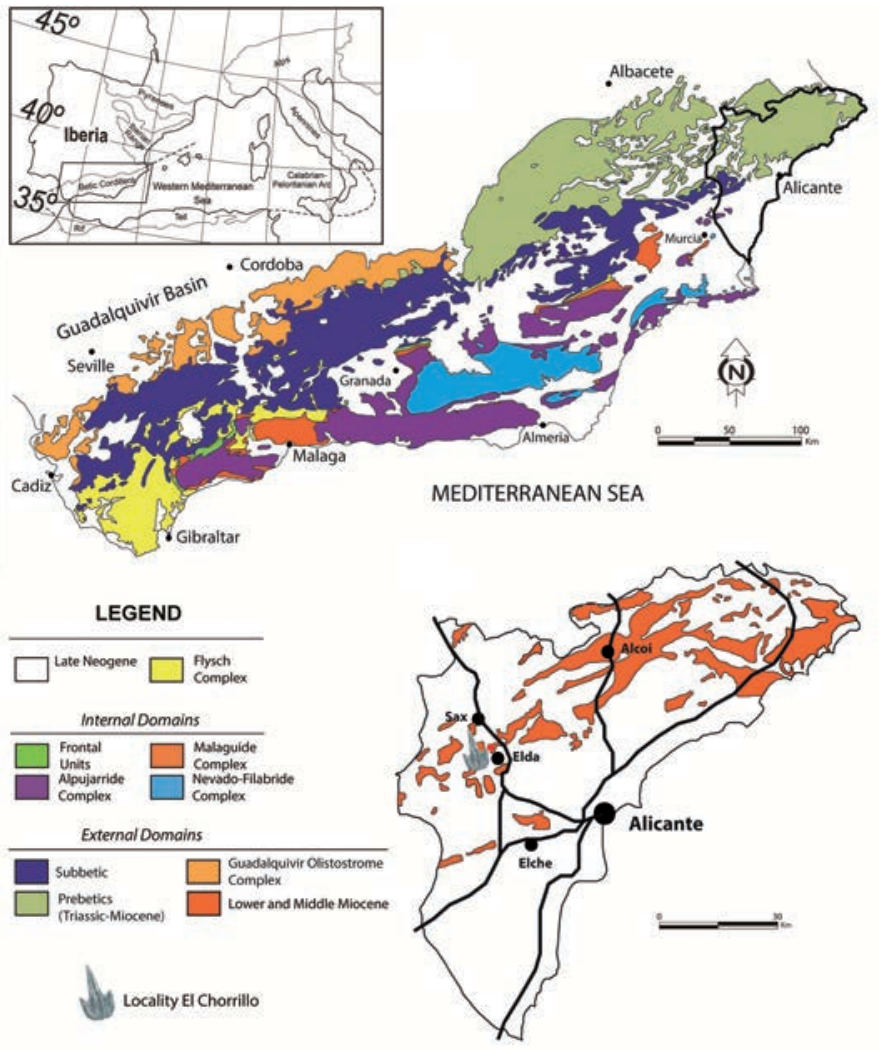

Figure 1. Major divisions of the Betic Cordillera and location of the 'El Chorrillo' section in the middle Miocene of the Alicante Province. Modified from MartínezPérez et al. (2018).

de la Universitat de València d'Història Natural (MGUV). Besides, five additional dermal denticles coming from previous palaeontological campaigns in "El Chorrillo" outcrop (Martínez-Pérez et al., 2018) were incorporated to the morphometric analysis.

For the morphometric and multivariate analyses, only dermal denticles with complete crowns or showing minimal fragmentation were considered. We performed a traditional morphometric analysis by measuring ten metric variables on the dermal denticle crowns in dorsal view, some of which were later transformed in order to obtain adimensional variables (Table 1). Measured dermal denticles were then introduced as ungrouped specimens into the Canonical Variate Analysis 1 (CVA1) established in Ferrón \& Botella (2017) considering adimensional variables as discriminant variables. This allowed their assignment into the different shark dermal denticle morphotypes and functional types considered in that work (see Table 2). The original CVA-1 performed by Ferrón \& Botella (2017) was based on 56 dermal denticles constituting a good representation of all the morphologies and functional types described in sharks.
Table 1. Description of the variables measured on the crown surface of "El Chorrillo" dermal denticles and the size-free variables included in the Canonical Variate Analysis-1 (CVA-1) performed by Ferrón \& Botella (2017).

\begin{tabular}{ll}
\hline Measured variables & Variables in the analysis \\
\hline MLC (Maximum Length of Crown) & MLC/MWC \\
MWC (Maximum Width of Crown) & RLA/MLC \\
RLA (Ridge Lenght Average) & RLA $^{2} / \mathrm{ACS}$ \\
LLR (Length of the Longest Ridge) & (MLC*MWC)/ACS \\
LSR (Length of the Shortest Ridge) & LLR/MLC \\
ACS (Area of the Crown Surface) & (LLR-LSR)/MLC \\
CP (Crown Perimeter) & CP/MLC \\
Circularity [ $\left.* * *\left(A C S / C P^{2}\right)\right]$ & Circularity \\
Roundness $\left[4 * A C S /\left(\pi *\right.\right.$ Major axis $\left.\left.{ }^{2}\right)\right]$ & Roundness \\
Solidity (ACS/Convex area) & Solidity \\
\hline
\end{tabular}

\section{RESULTS}

A total of 24 dermal denticles were collected, of which 18 were complete enough to be included in the morphometric and multivariate analysis. Five morphotypes corresponding to four different functional types were recognized by the analysis (Figs. 2-3; Table S1). One dermal denticle (MGUV-36339) was assigned to defensive dermal denticles against ectoparasites and epibionts (morphotype 4) being characterized by a large $(\sim 1100 \mu \mathrm{m}$ in total length) spine-like crown with the main cusp pointing in an upward-posterior direction and the presence of a long central ridge (Fig. 3a). Six dermal denticles (MGUV35884, MGUV-36329, MGUV-36330-31, MGUV-36334, MGUV-36338) were classified into drag reduction dermal denticles (morphotype 5) showing parallel long ridges on comparatively small crowns $(\sim 300$ to $550 \mu \mathrm{m})$. The number of ridges varies between four and seven in most cases and the distance between them ranges approximately from 60 to $150 \mu \mathrm{m}$ depending on the dermal denticle (Fig. 3b). Only one dermal denticle (MGUV-36338) constitutes an exception to this pattern, showing more than 10 ridges and a considerably larger crown $(\sim 1100 \mu \mathrm{m})$ (Fig. 3c). Seven dermal denticles (MGUV-35885a-d, MGUV36337, MGUV-36343, MGUV-36348) were included within dermal denticles that protect against abrasion, being characterized by the possession of thick rounded or oval crowns showing smooth surface (morphotype 6) 
Table 2. Dermal denticle morphotypes and functional types considered in Ferrón \& Botella (2017) and their occurrences in the different ecological groups. Taken from Ferrón et al. (2018). *Dermal denticle drawings modified from Compagno (1984a, 1984b, 2001).

\begin{tabular}{|c|c|c|c|}
\hline Functional type & Morphotypes & Drawing* & $\begin{array}{l}\text { Occurrence in ecological } \\
\text { groups }\end{array}$ \\
\hline $\begin{array}{l}\text { Accommodation of } \\
\text { photophores }\end{array}$ & $\begin{array}{l}\text { m. 1: Dermal denticles } \\
\text { with large crowns and } \\
\text { concave facets }\end{array}$ & & \\
\hline $\begin{array}{l}\text { Accommodation of } \\
\text { photophores }\end{array}$ & $\begin{array}{l}\text { m. 2: Dermal denticles } \\
\text { with long bristle-like } \\
\text { crowns }\end{array}$ & & $\begin{array}{l}\text { Exclusive of mesopelagic } \\
\text { luminescent species }\end{array}$ \\
\hline $\begin{array}{l}\text { Accommodation of } \\
\text { photophores }\end{array}$ & $\begin{array}{l}\text { m. 3: Dermal denticles } \\
\text { with hook-like or thorn- } \\
\text { like crowns }\end{array}$ & & \\
\hline $\begin{array}{l}\text { Defence against } \\
\text { ectoparasites and } \\
\text { epibionts }\end{array}$ & $\begin{array}{l}\text { m. } 4 \text { : Dermal denticles } \\
\text { with spine-like crown } \\
\text { with the main cusp } \\
\text { pointing in an upward- } \\
\text { posterior direction }\end{array}$ & & $\begin{array}{l}\text { Predominant in schooling } \\
\text { species of low to moderate } \\
\text { speed }\end{array}$ \\
\hline Drag reduction & $\begin{array}{l}\text { m. } 5 \text { : Dermal denticles } \\
\text { with parallel long ridges }\end{array}$ & & $\begin{array}{l}\text { Exclusive of strong- } \\
\text { swimming pelagic species }\end{array}$ \\
\hline $\begin{array}{l}\text { Protection against } \\
\text { abrasion }\end{array}$ & $\begin{array}{l}\text { m. 6: Dermal denticles } \\
\text { with large and } \\
\text { thickened smooth } \\
\text { crown }\end{array}$ & & $\begin{array}{l}\text { Predominant in demersal } \\
\text { sharks on rocky and/or sandy } \\
\text { and muddy substrates but } \\
\text { present also in other }\end{array}$ \\
\hline $\begin{array}{l}\text { Protection against } \\
\text { abrasion }\end{array}$ & $\begin{array}{l}\text { m. } 7 \text { : Dermal denticles } \\
\text { with large and } \\
\text { thickened ornamented } \\
\text { crown }\end{array}$ & & $\begin{array}{l}\text { body areas subjected to an } \\
\text { abrasive stress }\end{array}$ \\
\hline $\begin{array}{l}\text { Generalized } \\
\text { functions }\end{array}$ & $\begin{array}{l}\text { m. 8: Dermal denticles } \\
\text { with long ridges and } \\
\text { usually well developed } \\
\text { lateral wings }\end{array}$ & & $\begin{array}{l}\text { Predominant in slow species } \\
\text { of the open water but present } \\
\text { in other ecological groups }\end{array}$ \\
\hline
\end{tabular}

or being strongly ornamented with prominent short ridges (morphotype 7) (Figs. 3d-3e, respectively). These dermal denticles display a wide range of sizes with crowns that varies from 300 to $1700 \mu \mathrm{m}$. Finally, four dermal denticles (MGUV-36332-33, MGUV-36335, MGUV-36344) were assigned to dermal denticles with generalized functions (morphotype 8), all of them presenting medium-sized crowns (500 to $700 \mu \mathrm{m}$ ), long noticeable ridges and, most of them, well-developed wings or lateral expansions (Fig. 3f). One dermal denticle (MGUV-36344) classified in such functional type shows also characteristic concave facets on the most anterior part of the crown and the distal part of the lateral expansions (Fig. 3g). 
Posterior probabilities (i.e., probability of belonging to a given group) are high, very close to 1 in most of cases and above 0.7 in all cases (Table S1). With few exceptions, Mahalanobis distance to the centroid and conditional probabilities (i.e., probability of obtaining a discriminant punctuation as obtained or more extreme within a given group) of analysed dermal denticles are similar to those of the morphotypes and functional types to which they have been assigned (compare Table S1 with Ferrón \& Botella, 2017: S6 Table C) (see also Fig. 2). Together, these results support that the assignments of dermal denticles from "El Chorrillo" outcrop into morphotypes and functional types have been done reliably.

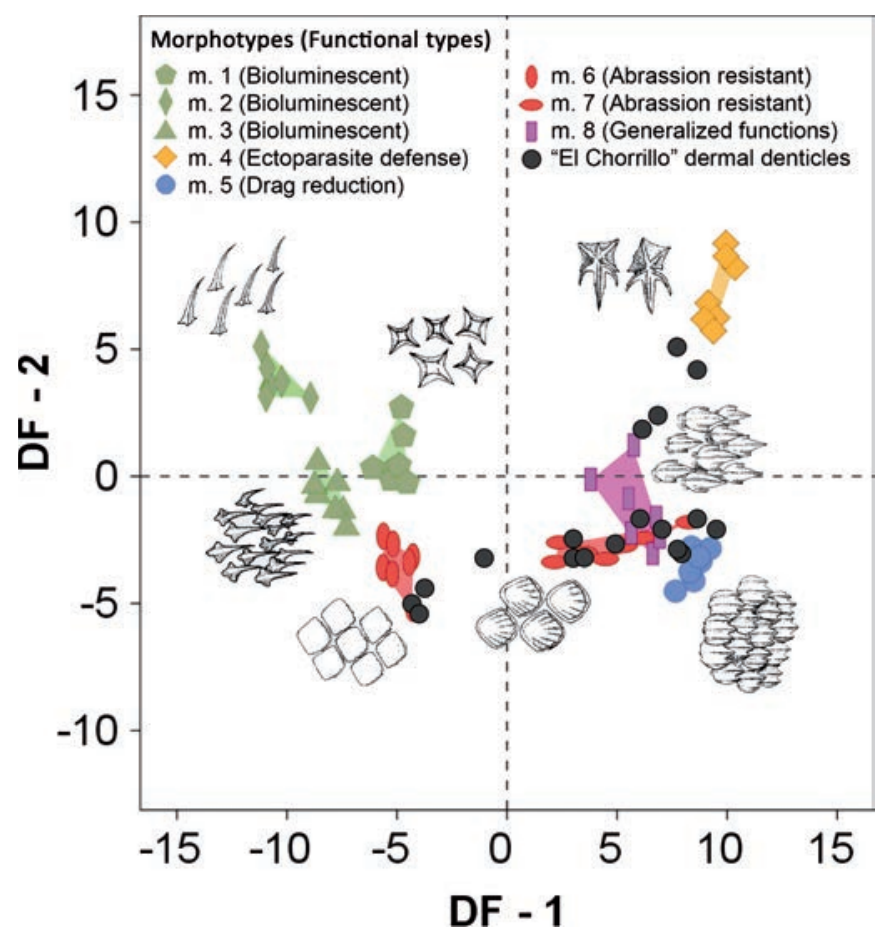

Figure 2. Canonical Variate Analyses results showing the discriminant punctuations of "El Chorrillo" dermal denticles. Results are plotted based on the first two discriminant functions (DF). The analysis was performed taking eight dermal denticle morphotypes (m. $1-\mathrm{m}$. 8, corresponding to five functional types) as defined groups and ten size-free variables of the crown surface as discriminant variables. Modified from Ferrón et al. (2018).

\section{DISCUSSION}

\subsection{Ecological diversity revealed by dermal denticle analysis}

Ecomorphological approaches on dermal denticles have been successfully applied in several works for basing ecological inferences in extinct taxa (Ferrón et al., 2014;
Dillon et al., 2017; Ferrón \& Botella, 2017). We applied here the comparative framework developed by Ferrón \& Botella (2017) to the dermal denticles sample from "El Chorrillo" outcrop in Alicante. Our results reveal a high diversity of dermal denticle morphotypes (including m.4-m.8 dermal denticles) being represented all considered functional types excepting dermal denticles that enable the accommodation of photophores (although see below). Ferrón \& Botella (2017) defined the squamation patterns typical of a number of ecological groups of sharks noticing the presence, distribution and coverage of their functional types. According to such information, the occurrence of different ecological groups in this locality can be inferred from our results. In this sense, the detection of defensive dermal denticles against ectoparasites and epibionts and drag reduction dermal denticles denotes the existence of schooling and strong-swimming pelagic species in the shark palaeocommunity of "El Chorrillo", as these dermal denticles seem to be exclusive of such lifestyles. Two ecological subgroups were defined by Reif \& Dinkelacker (1982) and Reif (1985a) in strong-swimming pelagic species on the basis of the distance between the ridges of their dermal denticles. Thus, fast pelagic hunting sharks such as lamnids and some carcharhinids show inter-ridge average distances comprised between 35 and $80 \mu \mathrm{m}$, whereas these values are typically above $80 \mu \mathrm{m}$ in slower large nearshore hunters. According to this, the range of inter-ridge distances showed by the dermal denticles of "El Chorrillo" assemblage suggests that these two ecological subgroups could be represented in our sample. Ecological inferences from the other two functional types detected by the analysis (i.e., dermal denticles that protect against abrasion and dermal denticles with generalized functions) are more difficult to be supported, as these can be found in more than one ecological group (Ferrón \& Botella, 2017). Abrasion resistant dermal denticles are common in demersal sharks living on sandy and muddy substrates or inhabiting rocky substrates or reefs. These dermal denticles are also found in all ecological groups covering small areas subjected to an important abrasive stress, such as the snout, the circumoral region or the claspers (see also Reif, 1978). Dermal denticles with generalized functions are usual in demersal sharks on sandy and muddy substrates and slow species of the open water, but can be also present in small proportions in schooling and mesopelagic luminescent species. In any case, the presence of these functional types could entail the existence of other different ecological groups and altogether reveals an important ecological diversity.

\subsection{Ecological diversity revealed by teeth analysis}

Alternative procedures for palaeoecological inferences on Mesozoic and Cenozoic neoselachians have been 


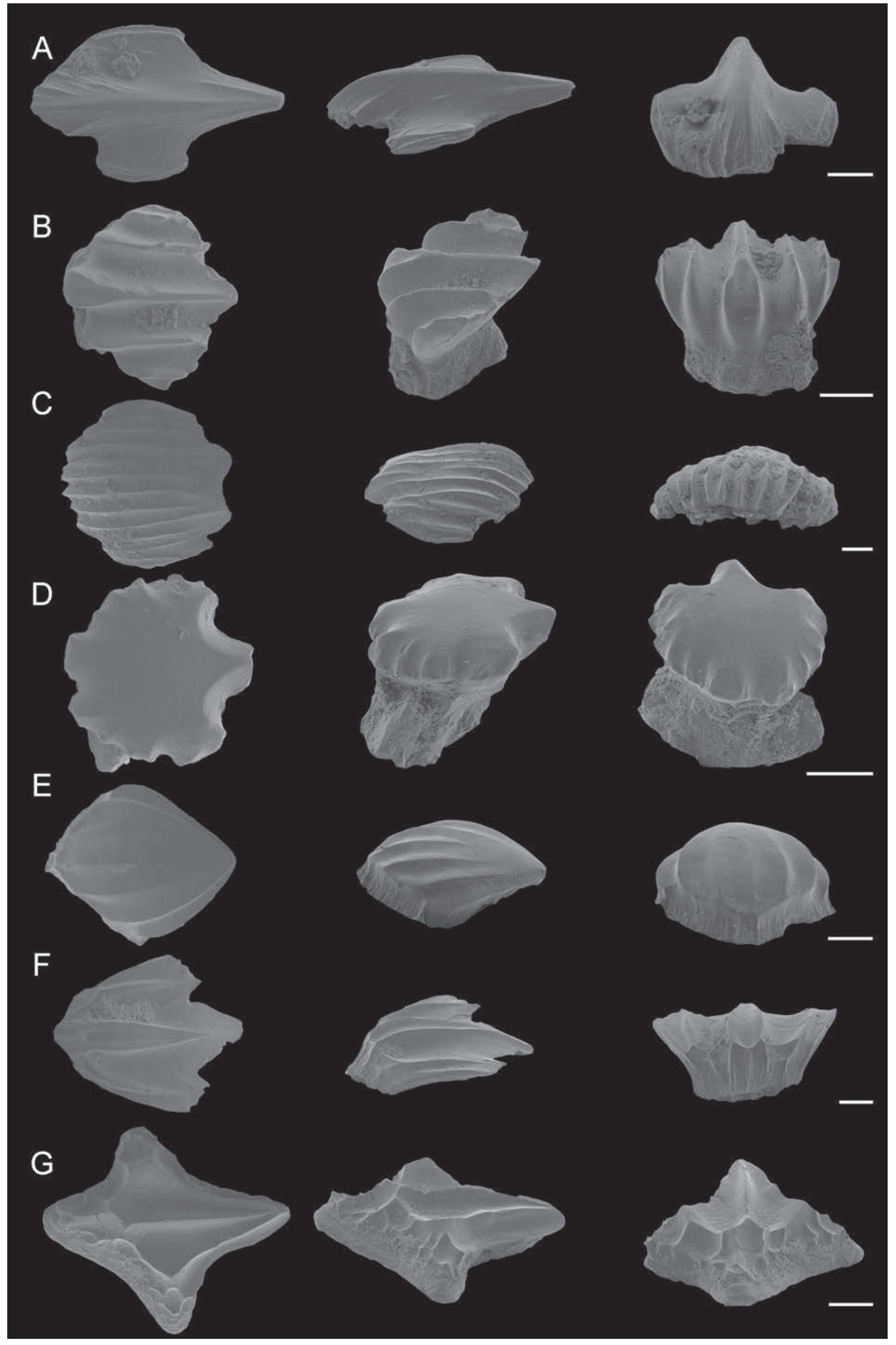


based on the assumption of ecological similitude with closely related living taxa, especially in species with extant representatives at family or generic level (e.g., Thies \& Müller, 1993; Adnet et al., 2008; Underwood \& Schlögl, 2012; Adolfssen \& Ward, 2014; Carrillo-Briceño et al., 2016, 2019; Perez et al., 2017; Martínez-Pérez et al., 2018). However, conclusions reached by this kind of proxies should be cautiously considered particularly when the ecological extrapolation entails large temporal or phylogenetic distance between the involved species. This is especially drastic if we consider that extant species belonging to the same family, or even the same genera, can display disparate lifestyles (Compagno et al., 2005; Ebert et al., 2013). Martínez-Pérez et al. (2018) provided a faunal listing of the chondrichthyans present in "El Chorrillo" outcrop from the study of dental remains noticing the presence of at least 13 different taxa (Deania calcea, Isistius triangulus, Squaliolus cf. S. schaubi, Paraetmopterus sp., Pristiophorus sp., Scyliorhinus sp., cf. Squaliformes indet, Cosmopolitodus hastalis, Isurus sp., Hemipristis serra, Odontaspis sp., Carcharhinus spp., and Otodus (Megaselachus) megalodon). Assuming ecological similarity with living relatives, we can argue that this association comprised taxa with disparate lifestyles. Thus, schooling species would be represented by Deania calcea and Pristiophorus sp., demersal species by Scyliorhinus sp., and strong-swimming species by Cosmopolitodus hastalis, Isurus sp., Hemipristis serra, Odontaspis sp., Carcharhinus spp., and Otodus (Megaselachus) megalodon. Beside this, an important number of the taxa described in MartinezPérez et al. (2018) putatively belong to bioluminescent groups (i.e., Isistius triangulus, Squaliolus cf. S. schaubi, Paraetmopterus sp.). However, dermal denticles that enable the accommodation of photophores were not recognized in our sample. This could be expected as dermal denticles of many bioluminescent sharks are covered by skin and are not discarded in life (Reif, 1985a, 1985b). However, taphonomic causes or sampling bias cannot be discarded. In any case, one of the dermal denticles classified within dermal denticles with generalized functions (MGUV36334) shows traits, such as the presence of concavities, that are exclusive of some bioluminescent groups playing an important role in the accommodation of photophores (see Reif, 1985b: figs. 4 and 5a-b; Reif, 1985a: plate 10). Note that similar concavities have only been described in one non-bioluminescent shark, i.e., Chlamydoselachus anguineus (Reif, 1985a: plate 1C2). These aspects were not considered by Ferrón \& Botella (2017) because of methodological restrictions of the discriminant analysis, which does not allow for the inclusion of characters that are not measurable in all the specimens to be analysed. As consequence, more broad approaches considering and combining both categorical (e.g., presence or absence of morphological traits) and quantitative data could be helpful in order to better characterize dermal denticle morphotypes and functional types, particularly regarding dermal denticles involved in bioluminescence. Notwithstanding this, ecological data based on information derived from dermal denticles and teeth seem to match properly in our study. However, ecomorphological approaches should be favoured in future studies dealing with ecological aspects of extinct taxa.

\subsection{Unravelling the impact of the Messinian salinity crisis in sharks}

Our results show that pre-Messinian communities of sharks from the western Mediterranean were ecologically diverse, paralleling the high taxonomical diversity described in previous studies (Martínez-Pérez et al., 2018 and references therein). The characterization of this ecological (and taxonomical) diversity is crucial to understand the recent evolutionary and palaeobiogeographic history of sharks and rays in this area, especially since the recent chondrichtyan diversity in the Mediterranean Sea shows a severe diversity impoverishment, mainly in the deep-water community (Perés, 1985; Marsili, 2008). The demise of Mediterranean deep-sea groups has been usually attributed to different aspects derived from the Messinian salinity crisis (e.g., Bouchet and Taviani, 1992; Krijgsman et al., 1999; Galil, 2004; Sardà, et al., 2004; Coll et al., 2010; among many others). However, the study of the shark and ray fossil record provides evidence supporting an important recolonization of the Mediterranean Sea during the Pliocene (Marsili, 2008) and as consequence other more recent geological events, such as the oxic-anoxic events during the Pleistocene-Quaternary (see RossignolStrick et al., 1982; Rohling 1994; Rohling et al., 2015), have been suggested as determinant factors in this sense (Martínez-Pérez et al., 2018). Therefore, the systematic application of the frame established in Ferrón \& Botella

Figure 3. Selection of shark dermal denticles from "El Chorrillo" outcrop, covering the whole diversity of morphotypes and functional types revealed by the Canonical Variate Analyses. a) Morphotype 4 corresponding to defensive dermal denticle against the settlement of ecotparasites and epibionts (MGUV-36339). b-c) Morphotype 5 corresponding to drag reduction dermal denticles (b) MGUV-36334, (c) MGUV-36338). d) Morphotype 6 corresponding to abrasion resistant dermal denticles (MGUV-36343). e) Morphotype 7 corresponding to abrasion resistant dermal denticles (MGUV-36337). f-g) Morphotype 8 corresponding to dermal denticles with generalized functions (f) MGUV-36333, (g) MGUV-36344). From left to right, dermal denticles are in dorsal, lateral and frontal views respectively. Scale bars: $\mathbf{a}-\mathbf{b}=200 \mu \mathrm{m} ; \mathbf{c}-\mathbf{g}=100 \mu \mathrm{m}$. 
(2017), or an equivalent ecomorphological approach, to Pliocene-Pleistocene shark dermal denticle assemblages of the Mediterranean could contribute to elucidate the impact of the Messinian salinity crisis and more recent events on current shark ecological diversity.

\section{CONCLUSIONS}

The morphometric study of the Serravallian shark dermal denticle assemblage of "El Chorrillo" outcrop from Alicante (southeast Spain) revealed a high functional diversity of dermal denticles that most likely correspond to an important ecological diversity of sharks. We found dermal denticles that protect against the settlement of ectoparasites and drag reduction dermal denticles, which most likely belonged to schooling and pelagic strong swimming species respectively. The finding of abrasion resistant dermal denticles and dermal denticles with generalized function denotes the possible presence of slow species associated to the open water and demersal species. Finally, no dermal denticles that enable the accommodation of photophores were recognized although one dermal denticle showed some traits typical of the dermal denticles of bioluminescent species. The methodology here applied has an important potential for assessing palaeoecological hypotheses in groups with micromeric squamations. In this sense, the application of this methodology for assessing the ecological diversity of Pliocene and Pleistocene fossiliferous sites will be crucial for disentangling the consequences of Messinian salinity crisis, and other recent geological events, on the ecological diversity of current Mediterranean shark communities.

\section{ACKNOWLEDGEMENTS}

This work was supported by the Spanish Society of Palaeontology (Project AJISEP-2017-07141). Humberto G. Ferrón is a recipient of a FPU Fellowship from the Spanish Ministry of Education, Culture and Sport (Grant FPU13/02660). We acknowledge the comments of the reviewers, Drs Hugo Martín Abad and Jorge CarrilloBriceño, that have considerably improved the final version of the manuscript.

\section{REFERENCES}

Adnet, S., Cappetta, H. \& Reynders, J. 2008. Contribution of Eocene sharks and rays from southern France to the history of deep-sea selachians. Acta Geologica Polonica, $58,257-260$.
Adolfssen, J.S. \& Ward, D.J. 2014. Crossing the boundary: an elasmobranch fauna from Stevns Klint, Denmark. Palaeontology, 57, 591-629; doi: 10.1111/pala.12079.

Ball, P. 1999. Engineering shark skin and other solutions. Nature, 400, 507-509; doi: 10.1038/22883.

Bechert, D.W, Hoppe, G. \& Reif, W.E. 1985. On the drag reduction of the shark skin. AIAA Shear Flow Control Conference, 23rd Aerospace Sciences Meeting, Aerospace Sciences Meetings, 85, 0546; doi: 10.2514/6.1985-546.

Bouchet, P. \& Taviani, M. 1992. The Mediterranean deep-sea fauna: Pseudopopulations of Atlantic species? Deep-Sea Research (Oceanographic. Research Papers), 39, 169-184; doi: 10.1016/0198-0149(92)90103-Z.

Carrillo-Briceño, J.D., Luz, Z., Hendy, A., Kocsis, L., Aguilera, O. \& Vennemann, T. 2019. Neogene Caribbean elasmobranchs: diversity, paleoecology and paleoenvironmental significance of the Cocinetas Basin assemblage (Guajira Peninsula, Colombia). Biogeosciences, 16, 33-56; doi: 10.5194/bg-16-33-2019.

Carrillo-Briceño, J.D., Aguilera, O.A., De Gracia, C., AguirreFernández, G., Kindlimann, R. \& Sánchez-Villagra, M.R. 2016. An Early Neogene Elasmobranch fauna from the southern Caribbean (Western Venezuela). Palaeontologia Electronica, 19.2.27A, 1-32.

Coll, M., Piroddi, C., Steenbeek, J., Kaschner, K., Lasram, F.B.R., Aguzzi, J., Ballesteros, E., Bianchi, C.N., Corbera, J. \& Dailianis, T. 2010. The biodiversity of the Mediterranean Sea: estimates, patterns, and threats. PloS one, 5, e11842; doi: 10.1371/journal.pone.0011842.

Compagno, L.J.V. 1984a. Sharks of the World. An Annotated and Illustrated Catalogue of Sharks Species Known to Date. Hexanchiformes to Lamniformes. FAO Fisheries Synopsis, Volume 4, Part 1.

Compagno, L.J.V. 1984b. Sharks of the World. An Annotated and Illustrated Catalogue of Sharks Species Known to Date. Carcharhiniformes. FAO Fisheries Synopsis, Volume 4, Part 2.

Compagno, L.J.V. 2001. Sharks of the World. An Annotated and Illustrated Catalogue of Sharks Species Known to Date. Bullhead, Mackerel and Carpet Sharks. Heterodontiformes, Lamniformes and Orectolobiformes. FAO Fisheries Synopsis, Volume 2.

Compagno, L.J.V., Dando, M. \& Fowler, S. 2005. Sharks of the World. Princeton University Press. 368 pp.

Dillon, E.M., Norris, R.D. \& Dea, A.O. 2017. Dermal denticles as a tool to reconstruct shark communities. Marine Ecology Progress Series, 566, 117-134; doi: 10.3354/meps12018.

Ebert, D., Fowler, S. \& Compagno, L. 2013. Sharks of the World. Plymouth: Wild Nature Press.

Ferrón, H.G. \& Botella, H. 2017. Squamation and ecology of thelodonts. PloS one, 12, e0172781; doi: 10.1371/journal. pone. 0172781.

Ferrón, H., Pla, C., Martínez-Pérez, C., Escudero-Mozo, M.J. \& Botella, H. 2014. Morphometric Discriminant Analysis of isolated chondrichthyan scales for palaeoecological inferences: the Middle Triassic of the Iberian Chain (Spain) as a case of study. Journal of Iberian Geology, 40, 87-97; doi: 10.5209/rev_JIGE.2014.v40.n1.44089. 
Ferrón, H.G., Paredes-Aliaga, M.V., Martínez-Pérez, C. \& Botella, H. 2018. Bioluminescent-like squamation in the galeomorph shark Apristurus ampliceps (Chondrichthyes: Elasmobranchii). Contributions to Zoology, 87, 187-196; doi: 10.1163/18759866-08703004.

Fulgosi, F.C. \& Gandolfi, G. 1983. Re-description of the external morphology of Somniosus rostratus (Risso, 1826), with special reference to its squamation and cutaneous sensory organs, and aspects of their functional morphology (Pisces Selachii Squalidae). Monitore Zoologico Italiano-Italian Journal of Zoology, 17, 27-70.

Galil, B.S. 2004. The limit of the sea: the bathyal fauna of the Levantine Sea. Scientia marina, 68, 63-72; doi: 10.3989/ scimar.2004.68s363.

Geel, T., Roep, T.B., Ten Kate, W. \& Smit. J. 1992. EarlyMiddle Miocene stratigraphic turning points in the Alicante region (SE Spain): reflections of Western Mediterranean plate-tectonic reorganizations. Sedimentary Geology, 75, 223-239; doi: 10.1016/0037-0738(92)90094-8.

Gibert, L., Scott, G.R., Montoya, P., Ruiz-Sánchez, F.J., Morales, J., Luque, L., Abella, J. \& Lería, M. 2013. Evidence for an African-Iberian mammal dispersal during the pre-evaporitic Messinian. Geology, 41, 691-694; doi: 10.1130/G34164.1.

Krijgsman, W., Hilgen, F.J., Raffi, I., Sierro, F.J. \& Wilson, D.S. 1999. Chronology, causes and progression of the Messinian salinity crisis. Nature, 400, 652; doi: $10.1038 / 23231$.

Marsili, S. 2008. Systematic, paleoecologic and paleobiogeographic analysis of the Plio-Pleistocene Mediterranean elasmobranch fauna. Atti Della Società Toscana Di Scienze Naturali Memorie Serie A, 113, 81-88.

Martínez del Olmo, W., Colodrón Gómez, I. \& Nuñez Galiano, A. 1978. Mapa Geológico de España escala 1:50000, 2a Serie (MAGNA). Hoja de Castalla, 846. Instituto Geológico y Minero de España.

Martínez-Pérez, C., Carrillo-Briceño, J.D., Esparza, C., Ferrón, H.G., Manzanares, E., Hammann, C. \& Botella, H. 2018. A Serravallian (Middle Miocene) shark fauna from Southeastern Spain and its palaeoenvironment significance. Historical Biology, 30, 422-432; doi: 10.1080/08912963.2017.1326111.

Muñoz-Chápuli, R. 1985. Sobre la clasificación tipológica del esqueleto dérmico de escualos (Chondrichtyes). Miscel-lània zoológica, 9, 396-400.

Perés, J.M. 1985. History of the Mediterranean biota and the colonization of the depths. In: Key Environments: Western Mediterranean (ed. Margalef, R). New York (NY): Pergamon Press, 198-232.
Perez, V.J., Pimiento, C., Hendy, A., González-Barba, G., Hubbell, G. \& MacFadden, B.J. 2017. Late Miocene chondrichthyans from Lago Bayano, Panama: Functional diversity, environment and biogeography. Journal of Paleontology, 91, 512-547; doi: 10.1017/jpa.2017.5.

Raschi, W.G. \& Musick, J.A. 1986. Hydrodynamic aspects of shark scales. NASA Contractor Report, 3963, 1-110.

Raschi, W. \& Tabit, C. 1992. Functional aspects of placoid scales: a review and update. Marine and Freshwater Research, 43, 123-147; doi: 10.1071/MF9920123.

Reif, W.E. 1978. Protective and hydrodynamic function of the dermal skeleton of elasmobranchs. Neues Jahrbuch für Geologie und Paläontologie, Abhandlungen, 157, 133-141.

Reif, W.E. 1982. Morphogenesis and function of the squamation in sharks. Neues Jahrbuch für Geologie und Paläontologie, Abhandlungen, 164, 172-183.

Reif, W.E. 1985a. Squamation and ecology of sharks. Frankfurt am Main: Courier Forschungsinstitut Senckenberg, 78, $1-255$.

Reif, W.E. 1985b. Functions of scales and photophores in mesopelagic luminescent sharks. Acta Zoologica, 66, 111-118; doi: 10.1111/j.1463-6395.1985.tb00829.x.

Reif, W.E. \& Dinkelacker, A. 1982. Hydrodynamics of the squamation in fast swimming sharks. Neues Jahrbuch für Geologie und Paläontologie, Abhandlungen, 164, 184-187.

Rohling, E.J. 1994. Review and new aspects concerning the formation of eastern Mediterranean sapropels. Marine Geology, 122, 1-28; doi: 10.1016/0025-3227(94)90202-X.

Rohling, E.J., Marino, G. \& Grant, K.M. 2015. Mediterranean climate and oceanography, and the periodic development of anoxic events (sapropels). Earth-Science Reviews, 143, 62-97; doi: 10.1016/j.earscirev.2015.01.008.

Rossignol-Strick, M., Nesteroff, W., Olive, P. \& VergnaudGrazzini, C. 1982. After the deluge: Mediterranean stagnation and sapropel formation. Nature, 295, 105; doi: 10.1038/295105a0.

Sardà, F., Canals, M., Tselepides, A., Calafat, A., Flexas, M.M., Espino, M. \& Tursi, A. 2004. An introduction to Mediterranean deep-sea biology. Scientia Marina, 68, 7-38; doi: 10.3989/scimar.2004.68s37.

Thies, D. \& Müller, A. 1993. A neoselachian fauna (Vertebrata, Pisces) from the Late Cretaceous (Campanian) of Höver, near Flannover (NW Germany). Paläontologische Zeitschrift, 67, 89-107; doi: 10.1007/BF02985872.

Underwood, C.J. \& Schlögl, J. 2012. Deep-water chondrichthyans from the early Miocene of the Vienna Basin (Central Paratethys, Slovakia). Acta Palaeontologica Polonica, 58, 487-509; doi: 10.4202/app.2011.0101. 
